\title{
MBO-Diploma 2010: Doorleren of werk zoeken?
}

Citation for published version (APA):

Huijgen, T. G., \& Meng, C. M. (2011). MBO-Diploma 2010: Doorleren of werk zoeken? ROA. ROA Fact

Sheets No. 001 https://doi.org/10.26481/umarof.2011001

Document status and date:

Published: 01/01/2011

DOI:

10.26481/umarof.2011001

Document Version:

Publisher's PDF, also known as Version of record

\section{Please check the document version of this publication:}

- A submitted manuscript is the version of the article upon submission and before peer-review. There can be important differences between the submitted version and the official published version of record.

People interested in the research are advised to contact the author for the final version of the publication, or visit the DOI to the publisher's website.

- The final author version and the galley proof are versions of the publication after peer review.

- The final published version features the final layout of the paper including the volume, issue and page numbers.

Link to publication

\footnotetext{
General rights rights.

- You may freely distribute the URL identifying the publication in the public portal. please follow below link for the End User Agreement:

www.umlib.nl/taverne-license

Take down policy

If you believe that this document breaches copyright please contact us at:

repository@maastrichtuniversity.nl

providing details and we will investigate your claim.
}

Copyright and moral rights for the publications made accessible in the public portal are retained by the authors and/or other copyright owners and it is a condition of accessing publications that users recognise and abide by the legal requirements associated with these

- Users may download and print one copy of any publication from the public portal for the purpose of private study or research.

- You may not further distribute the material or use it for any profit-making activity or commercial gain

If the publication is distributed under the terms of Article $25 \mathrm{fa}$ of the Dutch Copyright Act, indicated by the "Taverne" license above, 


\section{MBO-Diploma 2010: Doorleren of werk zoeken?}

\section{ROA Fact Sheet}

ROA-F-2011/1

Researchcentrum voor Onderwijs en Arbeidsmarkt | ROA Research Centre for Education and the Labour Market | ROA 


\section{Inleiding}

Het Researchcentrum voor Onderwijs en Arbeidsmarkt (ROA) heeft in het najaar van 2010 voor het tweede achtereenvolgende jaar een onderzoek verricht onder pas afgestudeerde schoolverlaters van het $\mathrm{MBO}$. Om zicht te krijgen op de gevolgen van de economische crisis en om de activiteiten rondom het School Ex programma in kaart te brengen zijn 20.000 MBO-schoolverlaters benaderd die in het schooljaar 2009/20Io hun BOL- of BBL-diploma behaald hebben. Dit betekent dat men gemiddeld genomen 5 maanden na het behalen van het diploma benaderd is. In totaal hebben 3.748 personen de internet vragenlijst ingevuld.

In dit fact sheet worden de kernresultaten van het onderzoek samengevat. Belangrijke vragen die hierbij aan de orde komen zijn: Welke activiteiten hebben scholen ondernomen om leerlingen te helpen bij hun studie- of beroepskeuze? In hoeverre heeft men hierbij de meest kwetsbare groepen kunnen behoeden voor een moeilijke start op de arbeidsmarkt? Hoe succesvol zijn de schoolverlaters die toch voor de arbeidsmarkt kiezen en wat is de rol van het UWV? Voor een uitgebreidere rapportage van dit, en de andere ROA schoolverlatersonderzoeken van de 2010 meting wordt verwezen naar het ROA rapport Schoolverlaters tussen Onderwijs en Arbeidsmarkt 2010 dat in de zomer van 201 verschijnt.

\section{Activiteiten van scholen}

In het kader van de economische crisis hebben scholen in het voorjaar van 2010 behalve de reguliere voorlichting extra activiteiten ondernomen om leerlingen te helpen bij hun studie- en beroepskeuze. Hierbij kan een tweetal typen van activiteiten onderscheiden worden: algemene activiteiten (bijvoorbeeld extra informatie verspreiden of extra aandacht door docenten voor de problematiek op de arbeidsmarkt) en persoonlijke gesprekken met leerlingen. Figuur I laat zien in hoeverre algemene activiteiten hebben plaatsgevonden. Figuur 2 geeft inzicht in de omvang van persoonlijke gesprekken.

Figuur 1

Door scholen ondernomen algemene activiteiten per onderwijsniveau \%

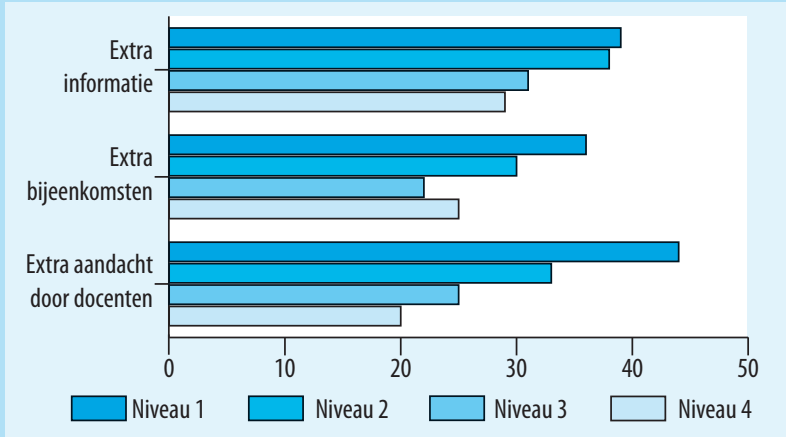

In totaal geeft $53 \%$ van de respondenten aan dat ten minste één algemene activiteit heeft plaatsgevonden. Onder de gediplomeerden van niveau I is dit zelfs $60 \%$. Met andere woorden, scholen hebben behoorlijk wat extra inspanningen verricht om leerlingen voor te lichten. Kijken we nader naar de verschillende algemene activiteiten (zie figuur I) dan zien we dat bijvoorbeeld $44 \%$ van de niveau I gediplomeerden aangeeft dat docenten extra aandacht hebben besteed aan de problematiek op de arbeidsmarkt. Onder de niveau 4 gediplomeerden ligt dit percentage aanzienlijk lager. Een vergelijkbaar beeld zien we als we kijken naar het percentage respondenten dat aangeeft dat de school extra informatie heeft verspreid of extra bijeenkomsten heeft georganiseerd. Naast de in de figuur vermelde resultaten geeft nog eens zo'n I $5 \%$ van de respondenten aan dat de school andere algemene activiteiten (bijvoorbeeld bezoek van een hogeschool) heeft georganiseerd. Algemene activiteiten zijn belangrijk maar kunnen persoonlijke gesprekken natuurlijk niet vervangen. Figuur 2 laat zien dat, vergelijkbaar met de meting in 2009, bijna I op de 2 respondenten met de school op individuele basis over zijn toekomstplannen heeft gesproken. Onder de gediplomeerden van niveau $\mathrm{I}$ is dit zelfs $53 \%$.

\section{Figuur 2}

Persoonlijke gesprekken per onderwijsniveau \%

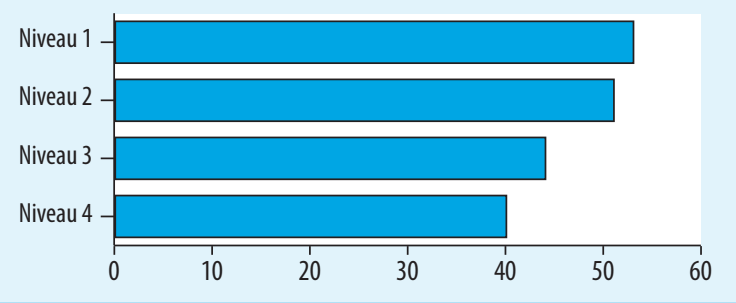

Hetgeen uit figuur I en 2 blijkt is ook in algemene zin uit de enquêteresultaten naar voren gekomen: scholen hebben zich met hun voorlichtingsactiviteiten met name gericht op de meest kwetsbare jongeren, namelijk de niveau I en 2 gediplomeerden. Over het gehele MBO geeft toch nog één van de drie respondenten aan dat de school geen enkele activiteit ondernomen heeft. Hierbij dient opgemerkt te worden dat voor een groot deel van hen voorlichting niet relevant was omdat hun keuze al vaststond. Daarnaast blijkt uit de data dat dit niet voor scholen als geheel geldt.

Belangrijk is de vraag in hoeverre de schoolactiviteiten invloed hebben gehad op de keuze van de gediplomeerden omtrent wat zij na het behalen van het diploma zijn gaan doen. Uit tabel I blijkt dat voor 3 van de 4 respondenten geldt dat de schoolactiviteiten verder geen invloed hebben gehad op hun uiteindelijke keuze. Bij de anderen hebben de schoolinspanningen wel invloed gehad: maar liefst $19 \%$ is alsnog een vervolgopleiding gaan volgen of heeft zijn of haar opleidingskeuze aangepast. Ook hier geldt dat we er rekening mee dienen te houden dat voor een groot deel van de jongeren de keuze omtrent hun toekomstactiviteit al lang vaststond. Jongeren die al een baan in het vooruitzicht hadden en jongeren die zich al voor een vervolgopleiding 
aangemeld hadden zullen zich door de schoolactiviteiten minder hebben laten beïnvloeden.

Tabel 1

Hebben de activiteiten van de school invloed gehad op wat u na de opleiding bent gaan doen

\begin{tabular}{lr}
\hline Nee, geen invloed & $76 \%$ \\
Ja, ik ben alsnog verder gaan leren & $16 \%$ \\
Ja, ik heb een andere opleiding gekozen dan ik eerst van plan was & $3 \%$ \\
Ja, anders & $5 \%$ \\
\hline
\end{tabular}

Uit een nadere analyse van de data blijkt dat 'niet-westerse allochtonen' aanzienlijk vaker beïnvloed zijn dan 'westerse allochtonen' of 'autochtonen' en dat deze invloed afneemt naarmate het onderwijsniveau hoger is. Zo geeft $43 \%$ van de niet-westerse allochtonen aan beïnvloed te zijn, bij de westerse allochtonen is dit $29 \%$ en onder de autochtonen $2 \mathrm{I} \%$. Van de gediplomeerden van het MBO niveau $\mathrm{I}$ is $44 \%$ beïnvloed versus $19 \%$ van de gediplomeerden van $\mathrm{MBO}$ niveau 4. Dit is vergelijkbaar met de resultaten van de vorige meting en kan als positief worden beschouwd aangezien zowel 'niet-westerse allochtonen' als gediplomeerden van de 'lage' opleidingsniveaus zeker in tijden van een crisis een zwakkere positie op de arbeidsmarkt innemen (zie ook paragraaf 5). Behalve het verspreiden van brochures en het gebruik maken van websites voor extra informatieverschaffing verhogen alle andere drie algemene activiteiten (extra bijeenkomsten, aandacht van docenten en andere algemene activiteiten) de kans dat iemand alsnog besluit om verder te gaan leren. Bij de individuele gesprekken zijn het de gesprekken over de vervolgstudie die het meest aanzetten tot het volgen van een vervolgopleiding.

Het overgrote deel van de respondenten was tevreden over de gekregen voorlichting. Slechts zo'n I $8 \%$ was niet tot zeer ontevreden over de door de school aangeboden extra activiteiten.

\section{De School Ex kaart}

In het kader van het School Ex programma hebben scholen in het voorjaar aan hun leerlingen gevraagd wat ze van plan waren te gaan doen na het behalen van het diploma. Zo'n $60 \%$ van de jongeren gaf daarbij aan verder te gaan leren, $20 \%$ had al een baan en de overige $20 \%$ ging op zoek naar werk, wilde iets anders dan verder studeren of werken of wist het nog niet. In tabel 2 staat in hoeverre deze plannen van de leerlingen overeenkomen met hun werkelijke situatie op het moment van enquêteren dus in het najaar van 2010.

Tabel 2

Maatschappelijke positie op enquêtemoment versus School Ex kaart

\begin{tabular}{lcccc}
\hline & $\begin{array}{c}\text { Ik ga verder } \\
\text { leren }\end{array}$ & $\begin{array}{c}\text { Ik heb al } \\
\text { een baan }\end{array}$ & $\begin{array}{c}\text { Anders, } \\
\text { weet nog niet }\end{array}$ & $\begin{array}{c}\text { Niet } \\
\text { gevraagd }\end{array}$ \\
\hline Studie & $86 \%$ & $7 \%$ & $16 \%$ & $20 \%$ \\
Werk & $10 \%$ & $88 \%$ & $62 \%$ & $68 \%$ \\
Anders & $4 \%$ & $5 \%$ & $22 \%$ & $13 \%$ \\
\hline
\end{tabular}

In grote lijnen komen de antwoorden die men op de School Ex kaart heeft ingevoerd overeen met de situatie op enquêtemoment. $86 \%$ van de respondenten die aangegeven hebben een vervolgstudie te willen gaan volgen zijn dat daadwerkelijk ook gaan doen. Van de mensen die al een baan hadden tijdens de enquêtering in het kader van het School Ex programma is bijna 9 van de tien inderdaad werkzaam. Zorgwekkender is de groep die op de School Ex kaart al aangaf nog niet te weten wat te gaan doen. Van hen is maar liefst $22 \%$ in het najaar niet werkzaam en ook niet aan een studie bezig. Zeker voor deze laatste groep is de rol die de school kan spelen na het uitreiken van het diploma niet afgelopen. Tabel 3 laat namelijk zien dat bijna één op de vijf jongeren die in oktober noch op school zitten noch werkzaam zijn, het spijtig vindt dat hij of zij geen contact meer heeft met de oude school.

De jongeren die voor een vervolgopleiding hebben gekozen hebben logischerwijs het vaakst nog contact met hun school. Dit zal vaak zijn omdat hun oude school de school is waar ze ook hun vervolgopleiding volgen.

Tabel 3

Heeft men nog contact met school naar huidige situatie

\begin{tabular}{lccc}
\hline & Studie & Werk & Anders \\
\hline Nee, en is ook geen behoefte aan & $50 \%$ & $79 \%$ & $66 \%$ \\
Nee, is wel behoefte aan & $8 \%$ & $12 \%$ & $19 \%$ \\
$\mathrm{Ja}$ & $42 \%$ & $10 \%$ & $15 \%$ \\
\hline
\end{tabular}

\section{Vervolgstudie}

In het najaar van 2010 is $45 \%$ van de respondenten bezig met een studie. De belangrijkste redenen voor het volgen van een studie hebben te maken met persoonlijke -en kennisontwikkeling. Het verbeteren van de kansen op de arbeidsmarkt wordt slechts door I $6 \%$ als hoofdreden genoemd.

Figuur 3

Aansluiting vervolgonderwijs naar richting gevolgde opleiding \%

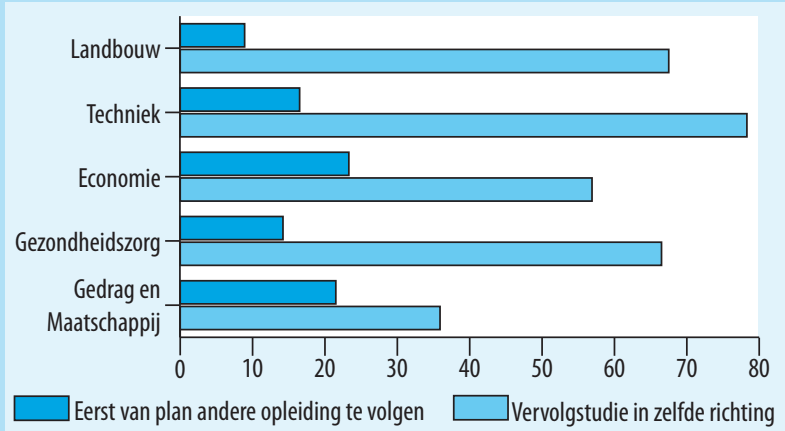

In figuur 3 staan enkele cijfers over de aansluiting tussen de gevolgde opleiding en de vervolgstudie. Respondenten met een technisch diploma op zak studeren het vaakst verder binnen de eigen richting, $78 \%$ van hen kiest een vervolgopleiding in de richting techniek. Ook gediplomeerden van de sectoren gezondheidszorg en landbouw gaan relatief 
vaak verder studeren in dezelfde richting. In tegenstelling tot verleden meetjaar zijn de gediplomeerden uit de sector landbouw daarbij vrij zeker over hun studiekeuze wat de vervolgopleiding betreft. Gediplomeerden uit de sectoren economie en gedrag en maatschappij zijn minder aan hun eigen richting gebonden als het gaat om hun vervolgstudie. Ze zijn daarnaast vaker van studiekeuze veranderd: meer dan $20 \%$ was eerst van plan een andere opleiding te gaan volgen.

Bij de vorige meting in het najaar van 2009 kwam naar voren dat de doorstroom van de lagere BOL niveaus naar de BBL gedaald was. Het lijkt er op dat deze doorstroom in de huidige meting weer enigszins is toegenomen. Van de verder lerende gediplomeerden van de BOL niveaus I en 2 stroomt zo'n 22\% door naar een BBL opleiding.

Een hoge doorstroom, al dan niet op aandringen van de oude school, naar het vervolgonderwijs is alleen waardevol indien men ook echt de intentie heeft om de vervolgstudie af te maken. In de vragenlijst is daarom gevraagd of men met de opleiding zou stoppen indien men een betaalde baan aangeboden zou krijgen. In totaal geeft $71 \%$ aan niet met de vervolgopleiding te stoppen, $5 \%$ geeft aan dit wel te doen en $24 \%$ twijfelt.

Figuur 4

Opgeven vervolgopleiding voor baan naar niveau gevolgde opleiding

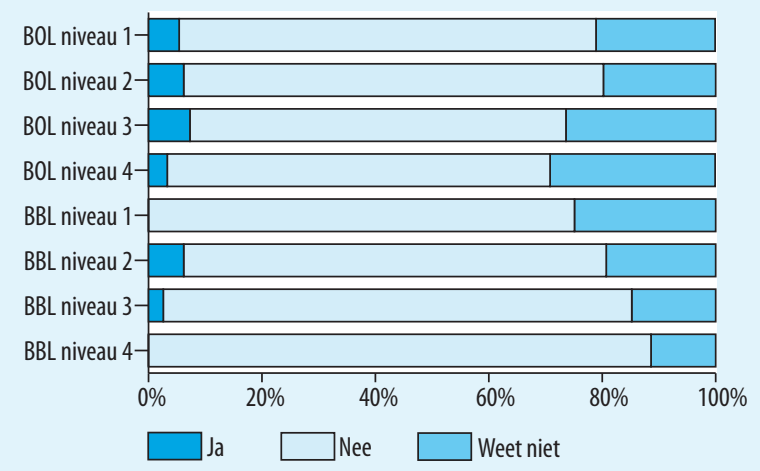

Figuur 4 toont dat de verder lerende BBL gediplomeerden in het algemeen minder vaak bereid zijn hun studie voor een baan op te geven. Dit zal deels er mee te maken hebben dat BBL gediplomeerden relatief vaker doorstromen naar de BBL dan de BOL gediplomeerden waardoor ze tijdens hun vervolgstudie al vaak baan en studie combineren. Een belangrijk punt dat eveneens uit figuur 4 naar voren komt is dat onder de BOL gediplomeerden de jongeren met een niveau I of 2 diploma het vaakst aangeven niet te willen stoppen met hun vervolgstudie. Zo'n $74 \%$ geeft aan niet met de opleiding te stoppen indien ze een baan aangeboden krijgen. Dit is een gunstig teken aangezien ze met hun niveau $\mathrm{I} / 2$ diploma weinig kansen maken op de arbeidsmarkt.

Evenals verleden meetjaar blijkt dat de groep jongeren die zegt beïnvloed te zijn door de voorlichting op school en alsnog verder is gaan leren iets minder vaak met de opleiding zal stoppen dan de groep leerlingen die niet beïnvloed is. De verschillen zijn weliswaar klein maar laten zien dat de eerste groep op zijn minst even gemotiveerd is om door te leren dan de tweede groep hetgeen aantoont dat de verschillende activiteiten zoals die door de scholen zijn ondernomen voor deze groep zeker zin hebben gehad.

\section{Arbeidsmarkt}

Van de ondervraagde gediplomeerden biedt $52 \%$ zich op het moment van enquêteren aan op de arbeidsmarkt. Van hen is op dat moment $12,2 \%$ werkloos $^{1}$. De werkloosheid onder de groep die verleden jaar ondervraagd is was iets hoger namelijk 13,6\%. Figuur 5 laat zien dat de werkloosheid echter sterk verschilt tussen de afgestudeerden van het $\mathrm{MBO}-\mathrm{BBL}$ en het MBO-BOL en dat het niveau een belangrijke factor is. Dat de niveau I gediplomeerden geen startkwalificatie hebben blijkt duidelijk uit de figuur. De laagst geschoolde BOL afgestudeerden hebben grote moeite om werk te vinden: meer dan de helft van hen is in oktober 2010 op zoek naar een baan. Ook in de BBL kennen de gediplomeerden zonder startkwalificatie de hoogste werkloosheid. Hiermee wordt dan ook nog een keer het belang benadrukt van activiteiten in het $\mathrm{MBO}$ specifiek gericht om deze groepen gediplomeerden in het onderwijs vast te houden.

Figuur 5

Werkloosheid na gevolgde opleiding \%

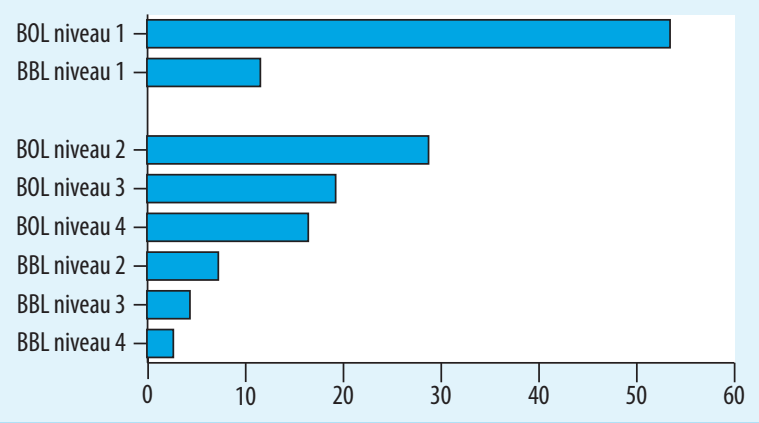

De werkloosheidspercentages variëren nogal per provincie. Figuur 6 toont welke provincies hogere werkloosheidscijfers kennen en welke lagere. Het blijkt dat men met name in de provincies Friesland (23,3\% werkloosheid) en Flevoland (2I\% werkloosheid) veel moeite heeft met het vinden van werk. Zeeland kent met 5,4\% het laagste percentage werklozen onder de pas afgestudeerde MBO gediplomeerden. Alhoewel deze verschillen deels verklaard kunnen worden door een relatief groter of kleiner aandeel van de BOL niveau I en 2 uitstroom in deze provincies spelen ook andere factoren, zoals regionale arbeidsmarktomstandigheden een rol.

I. De werkloosheid onder de recent gediplomeerden van het $\mathrm{MBO}$ is daarmee slechts marginal hoger dan de algemene werkloosheid onder jongeren in de leeftijd van $15-25$ jaar. Deze was in het derde kwartaal van $2010 \mathrm{II}, \mathrm{I} \%$ (CBS, Statline). 
Figuur 6

Werkloosheid naar woonprovincie

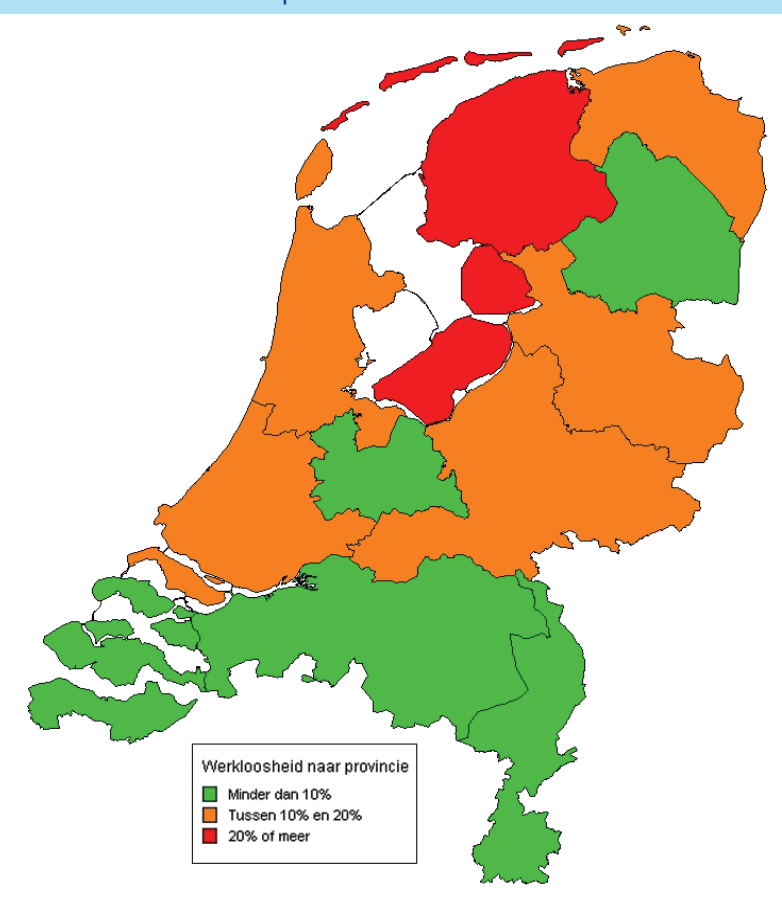

Van degenen die betaald werk hebben is het voor iets minder dan de helft de eerste baan, de anderen hebben reeds eerder betaalde werkzaamheden voor een kortere of langere periode verricht. Gemiddeld zijn ze na het behalen van hun diploma 0,4 maanden werkloos geweest hetgeen niet lang genoemd kan worden. Om een verdere indruk te krijgen van de overgang van het onderwijs naar de arbeidsmarkt is aan de werkende jongeren gevraagd hoeveel sollicitatiebrieven ze geschreven hebben en hoe vaak zij op sollicitatiegesprek geweest zijn. Tabel 4 geeft per opleidingsniveau het percentage weer dat minder dan 3 sollicitatiebrieven of minder dan 3 sollicitatiegesprekken nodig had om de huidige baan te vinden. Van de totale groep had $77 \%$ minder dan drie brieven nodig voor het vinden van werk. Binnen het $\mathrm{BOL}$ onderwijs ligt dit percentage lager dan binnen het $\mathrm{BBL}$ onderwijs dus daar heeft men iets meer moeite moeten doen. Zo'n $53 \%$ heeft overigens geen enkele sollicitatiebrief hoeven te schrijven. Zo'n 8 op de Io werkenden heeft minder dan drie sollicitatiegesprekken gehad. De overige $20 \%$ is drie of meer keren bij een potentiële werkgever op gesprek geweest.

Tabel 4

Aantal sollicitatiebrieven en sollicitatiegesprekken \%

\begin{tabular}{lcc}
\hline & $<3$ brieven & $<3$ gesprekken \\
\hline BOL 1/2 & 71 & 84 \\
BOL 3/4 & 71 & 81 \\
BBL 1/2 & 77 & 79 \\
BBL 3/4 & 84 & 83 \\
Totaal & 77 & 81 \\
\hline
\end{tabular}

Het niet hebben geschreven van een sollicitatiebrief impliceert dat men niet alleen een baan gevonden heeft door op bijvoorbeeld advertenties te reageren. Voor de werkende $\mathrm{MBO}$-ers zijn er vier manieren waarop men vaak aan een baan komt. Het reageren op een advertentie en het schrijven van een open sollicitatie zijn twee daarvan. Daarnaast worden veel banen gevonden via een eerder gelopen stage (met name onder de BOL gediplomeerden) en via vrienden, kennissen en familie. Het arbeidsbureau/UWV helpt zowel onder de BOL als de BBL gediplomeerden met name de lagere niveau opgeleiden aan werk. Het percentage dat aangeeft via het UWV werk gevonden te hebben is verder duidelijk gestegen. In meting 2009 gaf I\% van de gediplomeerde BOL niveau $\mathrm{I} / 2$ respondenten het UWV als belangrijkste kanaal aan. In 2010 was dit 5\%. Een vergelijkbare stijging zien we ook bij de gediplomeerden van BBL niveau I/2 (van $4 \%$ naar $8 \%$ ). Onder de werkende BBL-ers komt men ook nog regelmatig aan werk via eerder werk en/of een interne vacature, een vindkanaal dat vergelijkbaar is met 'via stage' onder de BOL werkenden.

Behalve het hebben van werk is het eveneens van belang wat de kwaliteit van deze baan is. Om hier enig zicht op te krijgen staan in tabel 5 enkele baankenmerken van de huidige functie. Het gaat hierbij om het percentage dat een vaste aanstelling heeft, het percentage dat binnen de eigen/verwante richting werkt, het percentage dat aangeeft op minimaal eigen niveau te werken, het bruto maandsalaris en het aantal arbeidsuren per week. Ter vergelijking vermeldt de tabel ook de cijfers voor MBO-totaal zoals deze in meting 2009 zijn vastgesteld.

Tabel 5

Kenmerken van de huidige functie

\begin{tabular}{lccccc}
\hline & $\begin{array}{c}\text { Vaste } \\
\text { aanstelling \% }\end{array}$ & $\begin{array}{c}\text { Eigen } \\
\text { domein \% }\end{array}$ & $\begin{array}{c}\text { Eigen } \\
\text { niveau \% }\end{array}$ & $\begin{array}{c}\text { Bruto } \\
\text { maandsalaris } €\end{array}$ & $\begin{array}{c}\text { Wekelijks } \\
\text { aantal uren }\end{array}$ \\
\hline BOL 1/2 & 41 & 54 & 66 & 881 & 28 \\
BOL 3/4 & 45 & 79 & 82 & 1.287 & 32 \\
BBL 1/2 & 69 & 58 & 63 & 1.486 & 33 \\
BBL 3/4 & 80 & 82 & 73 & 1.723 & 32 \\
Totaal & 64 & 73 & 73 & 1.469 & 32 \\
Cohort & & & & & \\
2008-2009 & 64 & 70 & 75 & 1.441 & 32 \\
\hline
\end{tabular}

Zoals uit de tabel blijkt doen de pas afgestudeerde MBO-ers het wat betreft baankenmerken niet direkt beter of slechter dan hun studiegenoten die een jaar eerder de arbeidsmarkt hebben betreden. Door de aard van de onderwijsvorm scoren de BBL gediplomeerden op het baankenmerk vaste aanstelling aanzienlijk hoger dan de BOL afgestudeerden. Gemiddeld verdient men $€$ I.469 per maand hetgeen zo'n $€$ 30 meer is dan onder de respondenten van dezelfde meting een jaar geleden. Zeker het gemiddeld aantal uren per week in ogenschouw nemend verdienen de pas afgestudeerden relatief goed. Zoals altijd zijn er wel aanzienlijke verschillen tussen de BOL en de BBL werkenden. Werkende BBL-ers hebben vaker al een langer arbeidsverleden en zijn gemiddeld genomen ouder dan hun werkende BOL studiegenoten. 


\section{Niet studerend en niet werkend}

Zo'n $9 \%$ van de respondenten heeft op het moment van de enquête geen betaald werk en is ook niet met een studie bezig. Deze groep bestaat dus uit jongeren die of op zoek naar werk zijn of zich (tijdelijk) teruggetrokken hebben van de arbeidsmarkt zonder met een opleiding gestart te zijn. Dit betekent niet dat niemand van deze gediplomeerden na het behalen van het diploma gewerkt heeft. Zowel onder de BBL als onder de BOL gediplomeerden geeft iets meer dan een derde aan nog geen betaald werk te hebben gehad na afstuderen. Dit vindt ook zijn weerslag in het gemiddeld aantal maanden dat ze werkloos zijn geweest in deze periode. Van de BOL gediplomeerden geeft $45 \%$ aan langer dan drie maanden werkloos te zijn geweest, onder de BBL gediplomeerden is dit percentage $39 \%$.

Ondanks dat een kwart van hen sinds het afstuderen nog geen enkele sollicitatiebrief verstuurd heeft is het merendeel actief op zoek naar een baan. $45 \%$ van hen heeft zelfs al meer dan 5 brieven de deur uit gedaan (zie tabel 6). Van de totale groep is $76 \%$ minder dan drie keer op een sollicitatiegesprek geweest. Uit de data blijkt dat van degenen die I of meerdere brieven verstuurd hebben er $30 \%$ is die nog nooit op een sollicitatiegesprek is geweest.

Tabel 6

Aantal sollicitatiebrieven en sollicitatiegesprekken \%

\begin{tabular}{lcc}
\hline & Brieven & Gesprekken \\
\hline$<3$ & 38 & 76 \\
$3-5$ & 17 & 17 \\
$>5$ & 45 & 7 \\
\hline
\end{tabular}

Van de gehele groep heeft $23 \%$ na het behalen van het diploma een aangeboden baan afgewezen. Zoals uit tabel 7 blijkt was dit voornamelijk omdat men het salaris te laag vond of de reisafstand als bezwaar zag.

Tabel 7

Ooit een aangeboden baan afgewezen \%

\begin{tabular}{lcccccc}
\hline & Ja & $\begin{array}{c}\text { Ja, want } \\
\text { salaris } \\
\text { waste } \\
\text { laag }\end{array}$ & $\begin{array}{c}\text { Ja, want ik } \\
\text { vond het } \\
\text { niveau te } \\
\text { laag }\end{array}$ & $\begin{array}{c}\text { Ja, want } \\
\text { het waste } \\
\text { ver weg }\end{array}$ & $\begin{array}{c}\text { Ja, want } \\
\text { ik vond } \\
\text { het bedrijf } \\
\text { niet leuk }\end{array}$ & $\begin{array}{c}\text { Ja, andere } \\
\text { reden }\end{array}$ \\
\hline MBO-BBL & 21 & 6 & 0 & 3 & 0 & 12 \\
MBO-BOL & 24 & 5 & 3 & 5 & 2 & 9 \\
Totaal & 23 & 6 & 2 & 4 & 2 & 10 \\
\hline
\end{tabular}

Toch is het niet zo dat men minder bereid is om voor een baan te reizen dan de wel werkenden. Figuur 7 toont de maximale tijd die men bereid is te reizen voor een baan en de actuele reistijd voor de groep werkenden. Uit de figuur komt duidelijk naar voren dat de niet werkenden langer willen reizen dan in de praktijk noodzakelijk is hetgeen betekent dat de mobiliteit geen belemmering zou moeten zijn voor het vinden van (passend) werk.
Figuur 7

Reistijd werkenden versus bereidheid te reizen niet werkenden

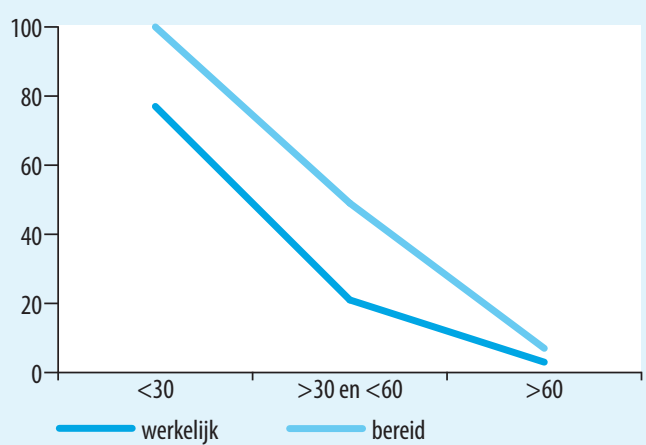

Wanneer gekeken wordt naar de toekomstplannen van deze groep gediplomeerden blijkt dat ondanks de niet al te beste situatie op de arbeidsmarkt meer dan de helft (54\%) van hen toch op zoek naar een baan wil gaan, hetzij zelfstandig, hetzij via het UWV (zie tabel 8). Een ander deel ziet toch een toekomst in het onderwijs: $7 \%$ begint binnenkort met een opleiding en IO\% gaat op zoek naar een geschikte studie. Een kwart van de totale groep niet werkenden/niet verder lerenden weet op het moment van enquêteren echter nog niet want hun plannen zijn voor de nabije toekomst.

Tabel 8

Plannen voor de nabije toekomst \%

\begin{tabular}{lccc}
\hline & $\begin{array}{r}\text { MBO- } \\
\text { BBL }\end{array}$ & $\begin{array}{r}\text { MBO- } \\
\text { BOL }\end{array}$ & $\begin{array}{c}\text { MBO- } \\
\text { Totaal }\end{array}$ \\
\hline ik ga op korte termijn beginnen met een opleiding & 4 & 8 & 7 \\
ik ga op zoek naar een opleiding & 6 & 11 & 10 \\
ik begin binnenkort met een baan & 7 & 6 & 6 \\
ik ga via het UWV op zoek naar werk & 23 & 19 & 20 \\
ik ga zelfstandig op zoek naar werk & 36 & 33 & 34 \\
dat weet ik nog niet & 25 & 24 & 24 \\
\hline
\end{tabular}

Gezien de slechte situatie op de arbeidsmarkt is het een voor de hand liggende vraag waarom men niet aan een nieuwe opleiding begint. De belangrijkste redenen om dit niet te doen hebben met name met de arbeidsmarkt te maken. Een groot deel (40\%) geeft aan een inkomen nodig te hebben en ook het feit dat men gewoon liever wil werken dan studeren is voor $36 \%$ een belangrijke reden om geen nieuwe studie te gaan volgen. Aan de onderwijskant zijn het met name de hoogte van de studiekosten die een nieuwe studie in de weg staan. Opvallend is ook dat een aanzienlijk deel nog steeds moeite heeft met het maken van een studiekeuze: $18 \%$ weet niet welke opleiding ze zouden willen volgen.

\section{Contacten met het UWV}

In het transitieproces van het onderwijs naar de arbeidsmarkt kan het UWV een belangrijke rol spelen. Aan de geënquêteerden is dan ook gevraagd of het UWV na het 
behalen van het diploma contact met hen heeft opgenomen. Een samenvatting van de resultaten staat in tabel 9 . Vergelijkbaar met de vorige meting geeft zo'n $78 \%$ aan dat het UWV geen contact met hen heeft opgenomen maar dat dit ook niet relevant was. Nog eens I2\% geeft eveneens aan dat dit niet het geval is maar dat ze hier wel prijs op zouden stellen. De resterende II\% heeft wel contact met het UWV, hetzij omdat ze zelf het initiatief hebben genomen hetzij omdat het UWV het initiatief heeft genomen.

Het is duidelijk dat het UWV niet met alle MBO gediplomeerden contact kan en hoeft op te nemen. Tabel 9 laat daarom ook de cijfers zien op basis van een onderscheid in een drietal groepen van jongeren, namelijk de jongeren die op het moment van enquête werkzaam zijn, de jongeren die een opleiding volgen en de jongeren die noch werkzaam noch studerend zijn (anders).

Tabel 9

Contact met het UWV naar huidige situatie \%

\begin{tabular}{lcccc}
\hline & $\begin{array}{c}\text { Volgt } \\
\text { opleiding }\end{array}$ & Is werkzaam & Anders & Totaal \\
\hline $\begin{array}{l}\text { Nee, maar dat is ook niet } \\
\text { nodig }\end{array}$ & 80 & 82 & 44 & 78 \\
Nee, maar dat zou men & 12 & 9 & 23 & 12 \\
wel fijn vinden & 3 & 5 & 25 & 6 \\
Ja, zelf benaderd & 5 & 4 & 8 & 5 \\
Ja, door UWV benaderd & & & & \\
\hline
\end{tabular}

Van de respondenten die een studie volgen geeft $80 \%$ aan geen contact met het UWV te hebben en dat dit ook niet nodig is. I $2 \%$ zou dit contact wel willen hebben en $8 \%$ heeft daadwerkelijk contact. Ook bij de werkzame respondenten heeft het merendeel geen contact met het UWV en een kleine groep wel. Bij de groep die geen studie volgt en niet werkzaam is liggen de percentages anders. $23 \%$ heeft weliswaar geen contact maar zou dit wel prettig vinden en $33 \%$ heeft op het moment van enquêteren wel op enige wijze contact met het UWV. Het feit dat bijna een kwart van deze groep geen contact met het UWV heeft maar dit wel zou willen, en dat daarnaast ook onder de groep werkenden en de groep scholieren een, weliswaar kleiner percentage, graag in contact zou komen met het UWV is ook al in de vorige meting als belangrijke uitkomst naar voren gekomen. Alhoewel het in eerste instantie dus lijkt alsof het UWV een belangrijke groep niet bereiken kan, is gebleken dat $74 \%$ van degenen die geen contact met het UWV heeft maar dit wel zou willen ooit aan de school heeft doorgegeven dat hun gegevens niet aan het UWV doorgegeven mogen worden. Dit zal voor een belangrijk deel verklaren waarom het UWV niet alle potentiële 'klanten' kan benaderen.

Van de jongeren die contact hebben, of hebben gehad met het UWV geeft $52 \%$ aan dat deze instantie hulp heeft aangeboden. De aangeboden hulp van het UWV kan uit verscheidene activiteiten bestaan variërend van een intakegesprek tot een bezoek aan een banenmarkt. Tabel io laat zien hoe vaak van de verschillende activiteiten gebruik is gemaakt.

Tabel 10

Activiteit naar aanleiding van contact met UWV

\begin{tabular}{ll}
\hline Activiteit & $\%$ ja \\
\hline Intakegesprek (gehad of heb dit binnenkort) & 65 \\
Aanbod ontvangen voor baan/leerplaats & 28 \\
Cursus/training aangeboden & 15 \\
Cursus/training gevolgd of binnenkort volgen & 8 \\
Bezoek gebracht aan banenmarkt & 17 \\
Beroepskeuzetest gedaan & 10 \\
\hline
\end{tabular}

Zo'n twee van de drie jongeren die contact met het UWV hebben zijn op een intakegesprek geweest. Daarnaast heeft $28 \%$ al een concreet aanbod mogen ontvangen voor een baan of een leerplaats en heeft $23 \%$ een cursus gevolgd of gaat deze binnenkort volgen.

Alhoewel het in sommige gevallen nog te vroeg is om het effect te meten van de aangeboden hulp van het UWV geeft $2 \mathrm{I} \%$ aan dat de hulp effectief geweest is. Voor een andere aanzienlijke groep (28\%) was de hulp niet meer nodig en $29 \%$ is nog steeds samen met het UWV bezig om een geschikte oplossing te vinden. Helaas geeft ook $22 \%$ aan dat ze geen contact meer hebben en dat de hulp van het UWV nergens toe geleid heeft. 
Researchcentrum voor Onderwijs en Arbeidsmarkt

Postbus 616

6200 MD Maastricht

$\mathrm{T}+31433883647$

$\mathrm{F}+31433884914$

secretary-roa-sbe@maastrichtuniversity.n|

www.roa.nl

Maastricht University

School of Business and Economics 